\title{
Grateloupia jejuensis (Halymeniales, Rhodophyta): a new species previously confused with G. elata and G. cornea in Korea
}

\author{
Su Yeon Kim ${ }^{1}$, Eun Gyu Han², Myung Sook Kim ${ }^{2, *}$, Jung Kwang Park ${ }^{1}$ and Sung Min Boo ${ }^{1}$ \\ ${ }^{1}$ Department of Biology, Chungnam National University, Daejeon 305-764, Korea \\ ${ }^{2}$ Department of Biology and Research Institute for Basic Sciences, Jeju National University, Jeju 690-756, Korea
}

\begin{abstract}
Despite specimens' large size and ease of collection in northeast Asian waters, the species diversity of the genus Grateloupia still needs more research in Korea. We investigated plastid $r b c \mathrm{~L}$ sequences and carried out detailed morphological observation on flattened halymeniacean red alga collected in twelve locations around Korea and Japan. We describe Grateloupia jejuensis sp. nov. based on the distinct clade with high support in our rbcL tree. Grateloupia jejuensis is characterized by solitary or caespitose habit and flattened thalli with discoid holdfast, cartilaginous texture, and blunt or bifid axis. Grateloupia jejuensis was distantly related to G. elata and G. cornea, which have been morphologically confused with the former, and it formed a sister relationship with Prionitis filiformis from California, USA in the $r b c$ L tree.
\end{abstract}

Key Words: Grateloupia; Grateloupia jejuensis; Halymeniales; Korea; new species; Rhodophyta

\section{INTRODUCTION}

The genus Grateloupia was established by C. Agardh (1822) based on G. filicina (J. V. Lamouroux) C. Agardh. Grateloupia is distinguished by Grateloupia-type auxiliary cell ampullae with a single primary ampullar filament and two or three 7 - to 13-celled secondary ampullar filaments of a conical out line (Chiang 1970, Kawaguchi 1989, Wang et al. 2000). Recent studies combining morphological and molecular data have resulted in several taxonomic changes. Pachymeniopsis Y. Yamada, Prionitis J. Agardh, Dermocorynus P. L. Crouan \& H. M. Crouan, and Phyllymenia J. Agardh have been merged into Grateloupia (Kawaguchi 1997, Wang et al. 2001, De Clerck et al. 2005b, Wilkes et al. 2005) while G. intestinalis (Harvey) Setchell moved to Glaphyrosiphon Hommersand \& Leister (Hommersand et al. 2010).

Grateloupia elata (Okamura) S. Kawaguchi \& H. W. Wang was described based on specimens under the name
Prionitis elata Okamura (type locality: Shirahama, Chiba Prefecture, located at the Pacific side of Japan). In Korea, Cotton (1906) reported this species (as Prionitis elata) for the first time at Wonsan on the northeast coast of the Korean peninsula. Afterwards, G. elata was reported between Busan and Gangneung on the east coast of Korea and Gapado on Jeju Island (Lee and Kang 2001).

Grateloupia cornea Okamura (1913) was transferred to the genus Carpopeltis and then changed to Prionitis cornea (Okamura) E. Y. Dawson (Dawson 1958). However, Wang et al. (2001) reinstated the original name, Grateloupia cornea, when they merged Prionitis into Grateloupia. In Korea, Kang (1966) reported this species on the east to south coasts and on Jeju Island. Subsequently, this species has been reported in many floristic reports (Lee and Kang 2001). (c) This is an Open Access article distributed under the terms of the Creative Commons Attribution Non-Commercial License (http://creativecommons.org/licenses/by-nc/3.0/) which permits unrestricted non-commercial use, distribution, and reproduction in any medium, provided the original work is properly cited.
Received April 12, 2013, Accepted August 21, 2013

*Corresponding Author

E-mail: myungskim@jejunu.ac.kr

Tel: +82-64-754-3523, Fax: +82-64-756-3541 
The taxonomy of the genus Grateloupia remains confused due to the low taxonomic utility of vegetative morphological characteristics, such as surface morphology, thallus habit and texture, and frequency of proliferations (Wang et al. 2001, De Clerk et al. 2005a, Wilkes et al. 2005). Recent studies show that the $r b c L$ gene is a suitable marker for taxonomic study of Grateloupia (Wang et al.
2000, Faye et al. 2004, Lee et al. 2009, Yang et al. 2013). In the present study, we analyzed $r b c \mathrm{~L}$ from unidentified specimens in Korea as well as other species and observed morphological characters. As a result, we describe Grateloupia jejuensis sp. nov. and discuss the phylogenetic relationships of G. jejuensis with the other species of the genus.

Table 1. Materials used in the present study

\begin{tabular}{|c|c|c|c|}
\hline Taxa & Collection data & Voucher No. & $\begin{array}{c}\text { GenBank } \\
\text { accession No. }\end{array}$ \\
\hline \multirow[t]{14}{*}{ Grateloupia jejuensis sp. nov. } & Donghae, East coast, Korea; Oct 27, 2012 & SKKU6 & KF156729 \\
\hline & Yangyang, East coast, Korea; Oct 27, 2012 & SKKU15 & KF156729 \\
\hline & Gijang, East coast, Korea; Feb 28, 2010 & P2433, CNU74 & KF156729 \\
\hline & Hado, Jeju, Korea; Oct 4, 2009 & G7034, G7035 & KF156729 \\
\hline & Jinhae, South coast, Korea; Jun 12, 2009 & G1169 & KF156729 \\
\hline & Dodu, Jeju, Korea; Jun 4, 2009 & G1482 & KF156729 \\
\hline & Yongwoondong, Jeju, Korea; Jul 11, 2011 & SH205, SH207 & KF156729 \\
\hline & Sungsan, Jeju, Korea; Apr 4, 2010 & GT096 & KF156729 \\
\hline & Sungsan, Jeju, Korea; May 5, 2010 & G119 & KF156729 \\
\hline & Ilkwa, Jeju, Korea; Nov 29, 2009 & G024 & KF156729 \\
\hline & Jongdal, Jeju, Korea; Apr 4, 2010 & GT093, GT074 & KF156729 \\
\hline & Jongdal, Jeju, Korea; May 29, 2010 & G117 & KF156729 \\
\hline & Udo, Jeju, Korea; Nov 8, 2009 & G012 & KF156729 \\
\hline & Misaki, Japan; Apr 30, 2010 & MI29, MI15 & KF156729 \\
\hline $\begin{array}{l}\text { G. americana S. Kawaguchi \& } \\
\text { H.W.Wang }\end{array}$ & Strawberry, Oregon, USA; Jun 17, 2003 & G227 & KF156730 \\
\hline $\begin{array}{l}\text { G. angusta (Okamura) S. Kawaguchi } \\
\text { \& H.W. Wang }\end{array}$ & Beomseom, Jeju, Korea; Mar 26, 2011 & GAJ-1 & KF156731 \\
\hline \multirow[t]{2}{*}{ G. asiatica Kawaguchi \&Wang } & Dadaepo, Geojae, Korea; Aug 24, 2009 & G3827 & KF156733 \\
\hline & Gijang, Busan, Korea; Feb 5, 2011 & SH162 & KF156732 \\
\hline G. divaricata Okamura & Jeoncheon, Donghae, Korea; Feb 7, 2010 & G3745 & KF156734 \\
\hline G. catenata Yendo & Hupohang, Uljin, Korea; Jan 11, 2002 & G51 & KF156735 \\
\hline \multirow[t]{2}{*}{ G. elliptica Holmes } & Gamchusa, Donghae, Korea; Mar 14, 2010 & SH16 & KF156737 \\
\hline & Vladivostok, Russia; Jul 25, 2002 & G075 & KF156736 \\
\hline \multirow[t]{2}{*}{ G. imbricata Holmes } & Gimnyoung, Jeju, Korea; Aug 24, 2006 & G1971 & KF156739 \\
\hline & Daesambudo, Yeosu, Korea; Sep 10, 2006 & G667 & KF156738 \\
\hline \multirow[t]{2}{*}{ G. lanceolata (Okamura) Kawaguchi } & Uhran, Haenam, Korea; Jan 21, 2010 & G3759 & KF156740 \\
\hline & Jeoncheon, Donghae, Korea; Feb 7, 2010 & G3744 & KF156741 \\
\hline \multirow[t]{2}{*}{ G. subpectinata Holmes } & Gamchusa, Donghae, Korea; Mar 14, 2010 & SH14 & KF156743 \\
\hline & Dalian, China; Oct 14, 2008 & G1693 & KF156742 \\
\hline \multirow[t]{2}{*}{ G. turuturu Yamada } & Sodol, Gangneung, Korea; Mar 14, 2010 & G3861 & KF156744 \\
\hline & Uhran, Haenam, Korea; Jan 21, 2010 & G3768 & KF156745 \\
\hline \multirow[t]{2}{*}{ Prionitis filiformis Kylin } & $\begin{array}{l}\text { A sunset at pescadero state beach, } \\
\text { California, USA; May 27, } 2010\end{array}$ & A671 & KF156746 \\
\hline & Bodega, California, USA; May 28, 2010 & P2762 & KF156747 \\
\hline $\begin{array}{l}\text { Polyopes affinis (Harvey) } \\
\text { Kawaguchi \& Wang }\end{array}$ & Uhran, Haenam, Korea; Jan 21, 2010 & G3772 & KF156748 \\
\hline
\end{tabular}




\section{MATERIALS AND METHODS}

In total, 38 specimens of 13 species in the Halymeniaceae were collected from Korea, China, Japan, Russia, and USA. Field observation and collections of Grateloupia jejuensis were made at intertidal zone of 12 locations around Korea and Japan from 2009 to 2012.

Specimens were sectioned with a freezing microtome (FX-801; Yamato Kohki Industrial Co. Ltd., Tokyo, Japan). Photographs were taken with a DP-71 camera (Olympus, Tokyo, Japan) attached to a microscope (BX 51; Olympus). Voucher specimens are housed at the herbarium of Chungnam National University, Daejeon, Korea (CNUK).

We analyzed 84 sequences representing 48 Halymeniaceae species, including 38 new sequences and 46 GenBank sequences. Information for specimens, their collection data, and GenBank accession numbers of $r b c \mathrm{~L}$ sequences are given in Table 1. DNA extraction, PCR amplification, and sequencing follow the procedures in Boo et al. (2010). For amplification and sequencing reaction of the $r b c \mathrm{~L}$ gene, specific primer pairs were $r b c \mathrm{LF} 145$ $r b c$ LR898 and rbcLF762-rbcLR1442 (Kim et al. 2010). Electropherogram outputs from each sample were edited using Chromas version 1.45 (http://www.technelysium. com.au/chromas.html). Eighty-nine $r b c \mathrm{~L}$ sequences were collated and aligned using Se-Al (version 2.0a11), as per Rambaut (2002). Maximum likelihood analyses were conducted using RAxML (Stamatakis 2006) with the GTR $+\Gamma$ evolutionary model. We performed 200 independent tree inferences using the -\# option with default -I (automatically optimized SPR rearrangement) and -c (25 distinct rate categories) option in the program to identify the best tree. To generate bootstrap values for the best phylogeny, we used 1,000 replications under the same program with the same model settings.

\section{RESULTS}

\section{Grateloupia jejuensis S. Y. Kim, E. G. Han \& S. M. Boo sp. nov. (Fig. 1)}

Thallus solitariam aut caespitosa, applanatis et dichotomis calami, saepe flabellatae in adumbration, apice cum terminus in obtunsus aut bifida, cartilaginous in textum. Cortex cum 7-8 compactus corticales cellulis, sphaericus in intimus cellulis et angulata superficies cellulis. Medulla cum parvos sphaericus cellulis, 5-7 $\mu \mathrm{m}$ in diametros. Tetrasporic sporophylls, tenuis et parvos, oblongae, acuminatus ad basin, seriatum per duo marginibus. Tetrasporangi- is cruciatis dividuus, plasmatio ex corticales cellam iacuit in the proliferous ramulis.

Thallus solitary or caespitose, flattened and dichotomous branches, often flabellate in outline, apex with ending in blunt or bifida, cartilaginous in texture. Cortex with 7-8 compact cortical cells, spherical in innermost cells and angulated surface cells. Medulla with small spherical cells, 5-7 $\mu \mathrm{m}$ in diameter. Tetrasporic sporophylls, thin and small, oblong, tapering at base, seriated along both margins. Tetrasporangia cruciately divided, forming from cortical cell layer in the proliferous branchlets.

Holotype. CNU040218, intertidal zone of Hado $\left(33^{\circ} 31^{\prime} \mathrm{N} 126^{\circ} 54^{\prime} \mathrm{E}\right)$, Jeju, Korea, Oct 4, 2009 (Fig. 1A), Herbarium of Chungnam National University (CNUK), Daejeon, Korea. Isotypes: CNU040217, -19, -220-1, NIBRAL0000138259-60.

Etymology. The specific epithet refers to Jeju Island, Korea, where the type was collected.

Distribution. Found from Gangneung on the east coast to Jinhae on the south coast, and from Ilkwari to Sungsan around Jeju Island. Grateloupia jejuensis was frequently found throughout the year on rocks in tide pools and sheltered places in lower tidal zones. Specimens were collected in February, June, July, October, and December; tetrasporophytes were collected in May and October. Gametophytes were not found.

Korean name. 댓잎도박

Morphology. Plants are solitary or caspitose, arising from discoid holdfast, and cartilaginous in texture. The thallus is dark purple to red in color and bright red in the upper portion. The thallus is $8-16 \mathrm{~cm}$ high, $0.2-0.4 \mathrm{~cm}$ wide, and 200-350 $\mu \mathrm{m}$ thick, with a short stipe $(0.5-1 \mathrm{~cm}$ long). Branches are divided up to eight times dichotomously, and apex endings are blunt or bifid. The marginal branches produce proliferous branchlets that are often irregular and small (up to $5 \mathrm{~mm}$ long and $1 \mathrm{~mm}$ wide), scattered over the middle part of the thallus except for the stipe and basal part. The internal thallus is composed of compacted cortex and dense medulla. The cortex is 7-8 cell layers and is $5-20 \mu \mathrm{m}$ in diameter. The outer cortex is composed of 3-4 layers with narrowly ellipsoidal cells, and the inner cortex is composed of 3-4 layers with irregular or rounded transparent cells. The medulla is composed of filamentous cells (5-7 $\mu \mathrm{m}$ in diameter). Tetrasporangia are formed from the cortical cell layer in the proliferous branchlets. The mature tetrasporangia are cruciately divided, narrowly ellipsoidal in shape, and 30-40 $\mu \mathrm{m}$ long by $10-15 \mu \mathrm{m}$ wide.

Phylogeny of $r b c \mathrm{~L}$. 1,094-nucleotide portions of the $r b c \mathrm{~L}$ gene were aligned for 84 sequences (38 new se- 

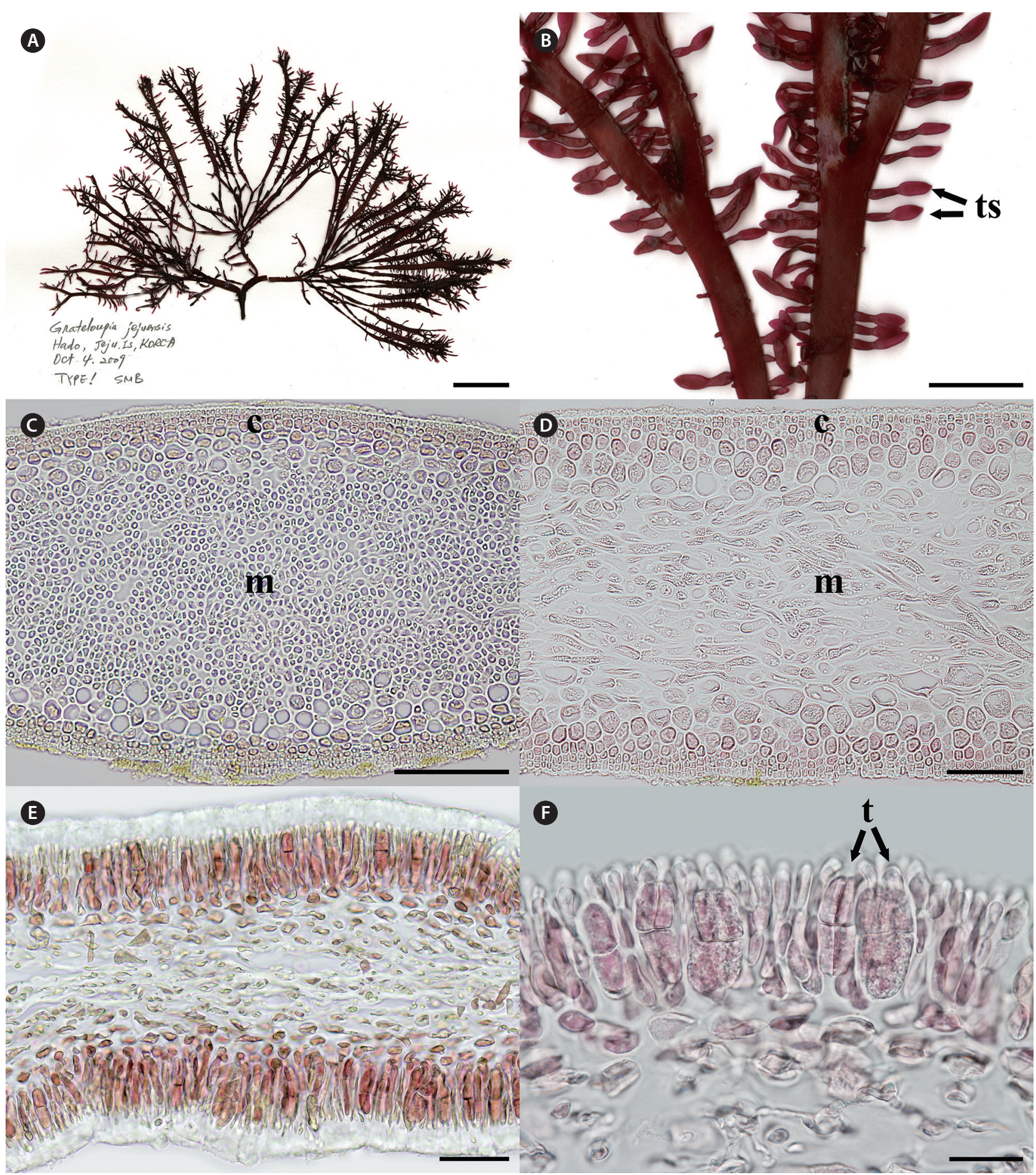

Fig. 1. Grateloupia jejuensis S. Y. Kim, E. G. Han \& S. M. Boo sp. nov. (A) Holotype (CNU040218, tetrasporophyte) of Grateloupia jejuensis collected from Hado, Jeju, Korea on Oct 4, 2009, deposited in the Herbarium of Chungnam National University (CNUK), Daejeon, Korea. (B) Close-up view of tetrasporic sporophylls (ts). (C) Cross section of thallus showing cortex (c) and medullar layers (m). (D) Longitudinal section of thallus showing cortex (c) and medullar layers (m). (E) Cross section of tetrasporic sporophylls. (F) Close-up view of a tetraspore (t). Scale bars represent: A, $2 \mathrm{~cm}$; B, $5 \mathrm{~mm} ; \mathrm{C}, 100 \mu \mathrm{m} ; \mathrm{D} \& \mathrm{E}, 50 \mu \mathrm{m} ; \mathrm{F}, 20 \mu \mathrm{m}$. 
quences), representing 48 species of Halymeniaceae. All sequences of G. jejuensis from 12 sites in Korea and Japan were identical. The $r b c \mathrm{~L}$ difference of G. jejuensis with Prionitis filiformis Kylin was 14-15 bp (1.28-1.37\%), while $G$. jejuensis differed by 27-29 bp (2.28-2.45\%) from G. elata and $63 \mathrm{bp}$ (5.48\%) from G. cornea.

In the phylogenetic tree (Fig. 2), Grateloupia jejuensis was placed in a single clade and clearly separated from the other species of the genus. The sister species of G. jejuensis was Prionitis filiformis (86\% for maximum likelihood). Grateloupia cornea was resolved as a sister taxon of G. chiangii from Japan with $91 \%$ bootstrap support. Grateloupia angusta shows sister relationships with G. elliptica and G. lanceolata.

\section{DISCUSSION}

The main finding of the present study is the discovery of a new species, Grateloupia jejuensis, in Korea based on $r b c \mathrm{~L}$ sequence data and morphological evidence. It had previously been misidentified as G. elata (Lee 2008) or G. cornea (Lee 1987) because of similarity in cartilaginous texture, and erect, linear, compressed habit. In this context, the existence of G. elata and G. cornea in Korea may be questionable.

The comparative morphology of Grateloupia jejuensis with similar species is summarized in Table 2. Grateloupia elata is much larger in thallus size than G. jejuensis (20$50 \mathrm{~cm}$ vs. 8-16 cm). Kawaguchi et al. (2001) reported that the difference in size is the one of main characteristics to distinguish G. asiatica from G. filicina $(10-30 \mathrm{~cm}$ vs. 9-12 $\mathrm{cm})$. The width of G. elata is less than that of G. jejuensis (1.5-2.5 $\mathrm{mm}$ vs. $2-4 \mathrm{~mm}$ ). The difference in habitat is also a remarkable characteristic between the two species: $G$. elata occurs in deep waters (Okamura 1899), whereas $G$. jejuensis usually occurs in tide pools and / or intertidal zone. Grateloupia cornea is also similar to G. jejuensis in having cartilaginous texture and linear habit. However, $G$. jejuensis has 7-8 cortical cell layers, while G. cornea has 13-15 cortical cell layers. The structure of medullary cells of $G$. jejuensis is more densely constructed than those of G. cornea.

Okamura (1899) stated that G. elata resembles G. angusta (Okamura) S. Kawaguchi \& H. W. Wang in structure, habit, and substance, but differed in fruit-bearing (tetraspores and cystocarps) portion and cells of the intermediated layer. G. angusta is distinguished from G. jejuensis by composition of medulla and number of cortical cells. G. jejuensis has a densely composed medulla with 7-8 cortical cells, while G. angusta has a very densely composed medulla with 14-16 cortical cells.

Wang et al. (2001) merged Prionitis to Grateloupia; however, the formal proposals were not for all species of Prionitis. The genus Prionitis is still used in the Halymeniaceae. In our $r b c \mathrm{~L}$ tree, P. filiformis was the sister of $G$. jejuensis and grouped together with all other Grateloupia species with high bootstrap support. It is therefore suggested that $P$. filiformis can be transferred to Grateloupia. Before taxonomic revision, a more detailed morphological study of $P$. filiformis is needed.

In the phylogenetic tree (Fig. 2), ten Korean species were grouped into four different subclades with strong bootstrap support. Grateloupia jejuensis was included in subclade I. Prionitis filiformis, P. sternbergii (C. Agardh) J. Agardh, Grateloupia americana from the northeast Pacific and Grateloupia acuminata Holmes, G. asiatica, G. divaricata, G. elata, G. jejuensis, G. livida (Harvey) Yamada, G. patens (Okamura) S. Kawaguchi \& H. W. Wang, G. schmitziana (Okamura) S. Kawaguchi \& H. W. Wang from

Table 2. Morphological comparison between Grateloupia jejuensis and the morphologically similar species

\begin{tabular}{lllll}
\hline & G. jejuensis sp. nov. & $\begin{array}{c}\text { G. elata (Okamura) } \\
\text { S. Kawaguchi \& H. W. Wang }\end{array}$ & $\begin{array}{l}\text { G. angusta (Okamura) } \\
\text { S. Kawaguchi \& H. W. Wang }\end{array}$ & $\begin{array}{c}\text { G. cornea } \\
\text { Okamura }\end{array}$ \\
\hline Texture & Cartilaginous & Rigid-cartilaginous & Strongly cartilaginous & Cartilaginous \\
Color & Dark purple to red & Red & Deep-blood red & Vinoso-purple \\
Habit & Cespitose, flattened & Densely cespitose, linear & Flattened and compressed & Cespitose, linear \\
Height $(\mathrm{cm})$ & $8-16$ & $20-50$ & $10-30$ & $15-20$ \\
Width (mm) & $2.0-4.0$ & $1.5-2.5$ & $1.5-2$ up to 5 & $1.0-2.0$ \\
Cortex (cells) & $7-8$ & $7-8$ & $14-16$ & $13-15$ \\
Medulla & Densely & Very dense & Very dense & Loosely set \\
Habitat & Tide pools, intertidal zones & Deep waters & Near low tide & Near high tide \\
Type locality & Hado, Jeju, Korea & Shirahama, Japan & Misaki, Japan & Kadzusa, Japan \\
Reference & This study & Okamura (1899) & Okamura (1912) & Okamura (1913) \\
\hline
\end{tabular}




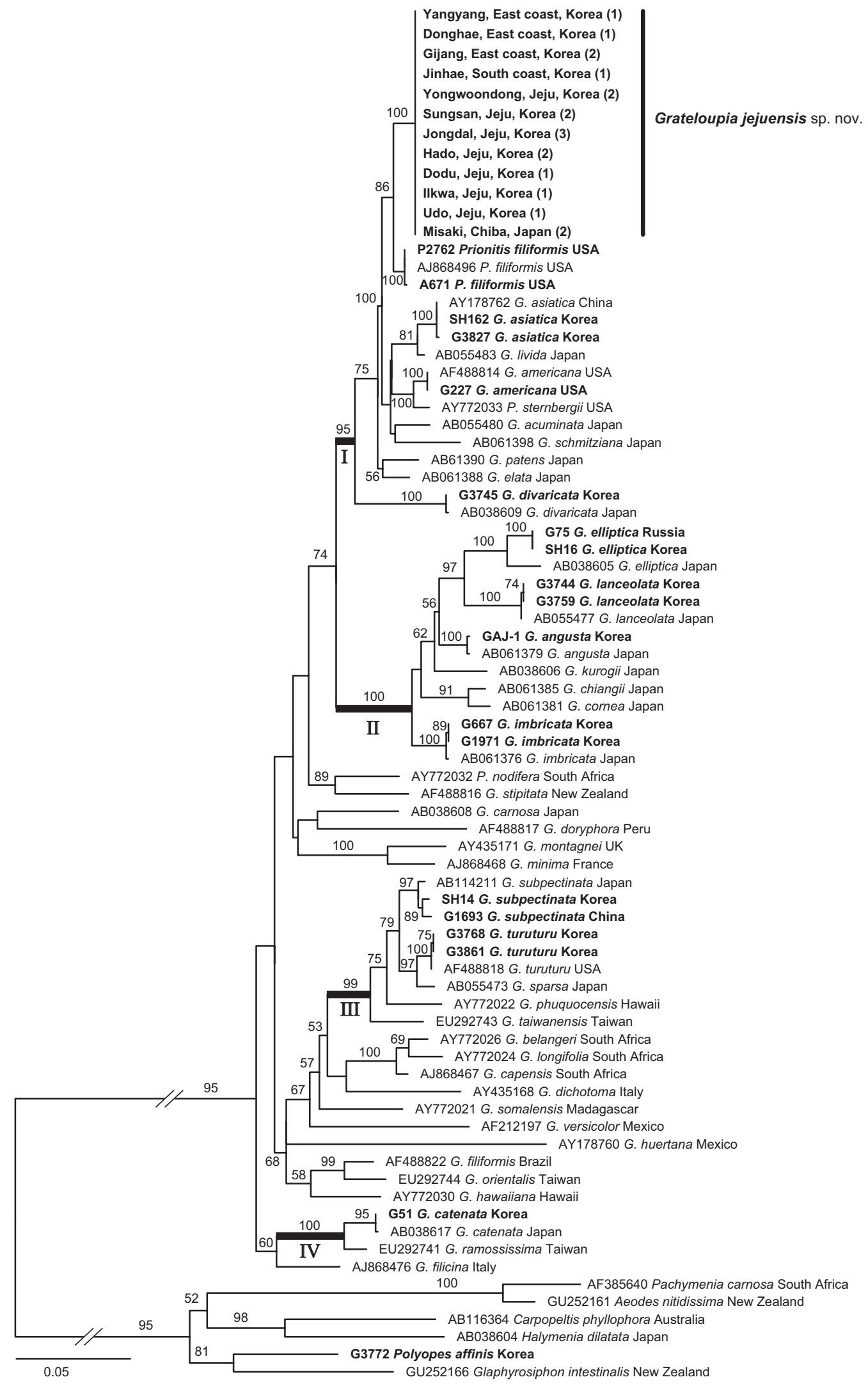

Fig. 2. Maximum likelihood (ML) tree inferred from $r b c \mathrm{~L}$ sequences calculated using the $\mathrm{GTR}+\lceil$ evolution model. Values above branches refer to ML bootstrap values. Bolded samples show the species which was newly analyzed in this study. 
the northwest Pacific, were mixed within this subclade, suggesting that many species were likely to have diverged in the north Pacific Ocean. Grateloupia cornea and G. angusta formed subclade II. Given the morphological similarity to G. jejuensis, the habit similarity is a result of convergence. This result is consistent with previous studies (Wang et al. 2001, De Clerk et al. 2005a, Wilkes et al. 2005, Lee et al. 2009). Thallus habits are homoplasious within Grateloupia; thus, additional taxon sampling will provide a better understanding of phylogenetic relationships of the species.

\section{ACKNOWLEDGEMENTS}

We thank Shigeo Kawaguchi for comments on the present work. This research was supported by MarineBio21 program grants from the Ministry of Maritime Affairs \& Fisheries, Korea to S. M. Boo and the National Institute of Biological Resources (NIBR), funded by the Ministry of Environment (MOE), Korea to M. S. Kim for collecting specimens.

\section{REFERENCES}

Agardh, C. A. 1822. Species algarum rite cognitae, cum synonymis, differentiis specificis et descriptionibus succinctis. Volumen primum pars posterior. ex officina Berlingiana, Lundae [Lund], pp. 169-398.

Boo, S. M., Kim, S. Y., Hong, I. S. \& Hwang, I. K. 2010. Reexamination of the genus Pterocladiella (Gelidiaceae, Rhodophyta) in Korea based on morphology and $r b c \mathrm{~L}$ sequences. Algae 25:1-9.

Chiang, Y. -M. 1970. Morphological studies of red algae of the family Cryptonemiaceae. Univ. Calif. Publ. Bot. 58:1-95.

Cotton, A. D. 1906. Marine algae from Corea. Bull. Misc. Inform. Kew. 1906:366-373.

Dawson, E. Y. 1958. Notes on Pacific coast marine algae, VII. Bull. South. Calif. Acad. Sci. 57:65-80.

De Clerck, O., Gavio, B., Fredericq, S., Barbara, I. \& Coppejans, E. 2005a. Systematics of Grateloupia filicina (Halymeniaceae, Rhodophyta), based on $r b c \mathrm{~L}$ sequence analyses and morphological evidence, including the reinstatement of G. minima and the description of G. capensis sp. nov. J. Phycol. 41:391-410.

De Clerck, O., Gavio, B., Fredericq, S., Cocquyt, E. \& Coppejans, E. 2005b. Systematic reassessment of the red algal genus Phyllymenia (Halymeniaceae, Rhodophyta). Eur. J. Phycol. 40:169-178.
Faye, E. J., Wang, H. W., Kawaguchi, S., Shimada, S. \& Masuda, M. 2004. Reinstatement of Grateloupia subpectinata (Rhodophyta, Halymeniaceae) based on morphology and $r b c L$ sequences. Phycol. Res. 52:59-67.

Hommersand, M. H., Leister, G. L., Ramírez, M. E., Gabrielson, P.W. \& Nelson,W. A. 2010. A morphological and phylogenetic study of Glaphyrosiphon gen. nov. (Halymeniaceae, Rhodophyta) based on Grateloupia intestinalis with descriptions of two new species: Glaphyrosiphon lindaueri from New Zealand and Glaphyrosiphon chilensis from Chile. Phycologia 49:554-573.

Kang, J. W. 1966. On the geographical distribution of marine algae in Korea. Bull. Pusan Fish. Coll. 7:1-125.

Kawaguchi, S. 1989. The genus Prionitis (Halymeniaceae, Rhodophyta) in Japan. J. Fac. Sci. Hokkaido Univ. Ser. V (Bot.) 14:193-257.

Kawaguchi, S. 1997. Taxonomic notes on the Halymeniaceae (Gigartinales, Rhodophyta) from Japan. III. Synonymization of Pachymeniopsis Yamada in Kawabata with Grateloupia C. Agardh. Phycol. Res. 45:9-21.

Kawaguchi, S., Wang, H. W., Horiguchi, T., Sartoni, G. \& Masuda, M. 2001. A comparative study of the red alga Grateloupia filicina (Halymeniaceae) from the Northwestern Pacific and Mediterranean with the description of Grateloupia asiatica, sp. nov. J. Phycol. 37:433-442.

Kim, M. S., Kim, S. Y. \& Nelson, W. 2010. Symphyocladia lithophila sp. nov. (Rhodomelaceae, Ceramiales), a new Korean red algal species based on morphology and $r b c \mathrm{~L}$ sequences. Bot. Mar. 53:233-241.

Lee, H. B. 1987. A systematic study of Halymeniaceae (Rhodophyta, Cryptonemiales) in Korea. Ph.D. disserration, Seoul National University, Seoul, Korea, 412 pp.

Lee, J. I., Kim, H. G., Geraldino, P. J. L., Hwang, I. K. \& Boo, S. M. 2009. Molecular classification of Grateloupia (Halymeniaceae, Rhodophyta) in Korea. Algae 24:231238.

Lee, Y. 2008. Marine algae of Jeju. Academy Publication, Seoul, $477 \mathrm{pp}$.

Lee, Y. \& Kang, S. 2001. A catalogue of the seaweeds in Korea. Cheju National University Press, Jeju, pp. 473-474.

Okamura, K. 1899. Contributions to the knowledge of Japan III. Bot. Mag. Tokyo 13:4-5.

Okamura, K. 1912. Icones of Japanese algae. Vol. 2. Kazamashobo, Tokyo, pp. 66-68.

Okamura, K. 1913. Icones of Japanese algae. Vol. 3. Kazamashobo, Tokyo, pp. 63-64.

Rambaut, A. 2002. Se-Al: Sequence alignment editor. Available from: http://tree.bio.ed.ac.uk/software/seal/. Accessed Apr 1, 2013.

Stamatakis, A. 2006. RAxML-VI-HPC: maximum likelihood- 
based phylogenetic analyses with thousands of taxa and mixed models. Bioinformatics 22:2688-2690.

Wang, H. W., Kawaguchi, S., Horiguchi, T. \& Masuda, M. 2000. Reinstatement of Grateloupia catenata (Rhodophyta, Halymeniaceae) on the basis of morphology and $r b c \mathrm{~L}$ sequences. Phycologia 39:228-237.

Wang, H. W., Kawaguchi, S., Horiguchi, T. \& Masuda, M. 2001. A morphological and molecular assessment of the genus Prionitis J. Agardh (Halymeniaceae, Rhodophyta). Phycol. Res. 49:251-261.
Wilkes, R. J., McIvor, L. M. \& Guiry, M. D. 2005. Using $r b c \mathrm{~L}$ sequence data to reassess the taxonomic position of some Grateloupia and Dermocorynus species (Halymeniaceae, Rhodophyta) from the north-eastern Atlantic. Eur. J. Phycol. 40:53-60.

Yang, M. Y., Han, E. G. \& Kim, M. S. 2013. Molecular identification of Grateloupia elliptica and G. lanceolata (Rhodophyta) inferred from plastid $r b c \mathrm{~L}$ and mitochondrial COI genes sequence data. Genes Genomics 35:239-246. 